\title{
Neurotrophins: Potential Therapeutic Tools for the Treatment of Spinal Cord Injury
}

\author{
Edmund R. Hollis II • Mark H. Tuszynski
}

Published online: 9 September 2011

(C) The American Society for Experimental NeuroTherapeutics, Inc. 2011

\begin{abstract}
Spinal cord injury permanently disrupts neuroanatomical circuitry and can result in severe functional deficits. These functional deficits, however, are not immutable and spontaneous recovery occurs in some patients. It is highly likely that this recovery is dependent upon spared tissue and the endogenous plasticity of the central nervous system. Neurotrophic factors are mediators of neuronal plasticity throughout development and into adulthood, affecting proliferation of neuronal precursors, neuronal survival, axonal growth, dendritic arborization and synapse formation. Neurotrophic factors are therefore excellent candidates for enhancing axonal plasticity and regeneration after spinal cord injury. Understanding growth factor effects on axonal growth and utilizing them to alter the intrinsic limitations on regenerative growth will provide potent tools for the development of translational therapeutic interventions for spinal cord injury.
\end{abstract}

Electronic supplementary material The online version of this article (doi:10.1007/s13311-011-0074-9) contains supplementary material, which is available to authorized users.

\author{
E. R. Hollis II \\ Neurobiology Section, Biological Sciences Division, \\ University of California-San Diego, \\ La Jolla, CA 92093-0366, USA \\ M. H. Tuszynski $(\bowtie)$ \\ Department of Neurosciences, \\ University of California-San Diego, \\ La Jolla, CA 92093-0626, USA \\ e-mail: mtuszynski@ucsd.edu \\ M. H. Tuszynski \\ VA Medical Center, \\ La Jolla, CA 92161, USA
}

Keywords Neurotrophin - spinal cord injury - regeneration · axon plasticity f functional recovery

\section{Human Spinal Cord Injury}

Traumatic injury of the spinal cord can produce a range of debilitating effects and permanently alter the capabilities and quality of life of its surviving victims. Damage to the central nervous system (CNS) in general results in destruction of neuronal circuitry. Contusion, compression, and penetration injuries of the spinal cord can interrupt the flow of sensory and motor information between the brain and periphery [1]. Depending on the location and severity of the injury, deficits can range from weakness of limb movement to total paralysis and ventilator-assisted respiration. Spontaneous functional recovery is limited, but can and often does occur in patients with initial sparing of sensorimotor function [2]. This recovery, which plateaus between 12 to 18 months, is very likely due to sparing and sprouting of axons within the zone of partial preservation, an area where some motor function remains intact, immediately adjacent to the lesion site [2].

Approximately $40 \%$ of humans that sustain spinal cord injury (SCI) exhibit improvement from their early postinjury baseline, and this spontaneous recovery can range from modest to extensive [2]. Spontaneous recovery primarily appears to depend on the extent of tissue sparing at the injury site, allowing compensatory axonal sprouting and systems reorganization at levels ranging from the spinal cord to the cerebral cortex [3-10]. However, in cases of more severe injuries, means of enhancing endogenous levels of axonal sprouting and inducing true axonal regeneration are required to enhance functional outcomes. 


\section{Clinical Treatment}

As there are no current clinical treatments that increase plasticity or regeneration of axons, the clinical field is restricted to attempting to limit the amount of secondary damage that follows SCI. The main goals of this approach are to stabilize the spinal column and minimize the secondary neural degeneration brought on by numerous factors including edema, hypoxia, ischemia, excitotoxicity, free radical damage, lipid peroxidation, inflammation, and activation of apoptosis [11, 12]. Acute spinal surgery, within the first $24 \mathrm{~h}$ following SCI, to alleviate mechanical shearing and compression forces is used to restrict primary damage to the cord, as well as secondary damage that can result from extended periods of compression [13]. In addition to spinal cord stabilization, arterial oxygenation and maintenance of mean arterial blood pressure between 85 and $90 \mathrm{~mm} \mathrm{Hg}$ following acute SCI is vital in reducing secondary damage due to ischemia and hypoxia, and improving functional outcome [11, 14-18]. Hypothermia is also currently in clinical testing as a means of limiting secondary damage immediately following injury $[19,20]$. However, progress in the translation of pre-clinical treatments aimed at promoting regenerative growth has been slow [21].

\section{Mechanisms Underlying the Failure of CNS Regeneration}

There are several obstacles hindering the functional regeneration of CNS circuitry. These include both neurondependent intrinsic and neuron-independent extrinsic mechanisms. Neuron-intrinsic mechanisms that contribute to regeneration failure include the absence of appropriate expression levels or localization of receptors capable of transducing growth signals, the modulation of growth factor signaling cascades, and the lack of expression of regeneration-associated genes, such as growth-associated protein 43 (GAP-43), which are indicative of an active axonal growth state [22-26].

A number of neuron-extrinsic factors affect the regenerative capacity of CNS neurons. These extrinsic factors include the absence of a growth-promoting substrate, inflammation following SCI, reactive astrogliosis, inhibitory extracellular matrix proteins, myelin inhibitory proteins, induction of repulsive guidance cues, and the lack of trophic support in the injured CNS [27-33]. There are numerous experimental strategies for targeting these extrinsic mechanisms, which include providing growth-promoting substrates, mediating the inflammatory response to SCI, eliminating reactive astrogliosis, reducing inhibitory extracellular matrix and myelin proteins, attenuating repulsive guidance signals, as well as providing growth-promoting neurotrophic signals.

In examining strategies aimed at promoting axonal growth through modulation of either intrinsic or extrinsic mechanisms, plasticity of axons can be divided into 2 main categories: 1) sprouting and 2) regeneration. Regeneration refers to new axonal growth that arises at the injury site from the cut end of an axon. Sprouting, on the other hand, refers to axonal growth emerging from a spared axon adjoining the lesion site, or from a transected axon at some distance from the site of transection.

\section{Provision of Growth-Promoting Substrates to Sites of Injury}

Pre-clinical research on SCI has focused primarily on the modulation of the extrinsic cellular environment with an emphasis on the differences between the relatively nonpermissive CNS environment for growth compared to the supportive peripheral nervous system environment. It has long been known that regeneration occurs following lesions to the peripheral nervous system, so it follows that the first attempts at bridging lesions in the CNS would graft segments of potentially permissive peripheral nerve. Grafting of peripheral nerve to the CNS dates back at least as far as the work of Ramón y Cajal in 1911 [34, 35]. Sugar and Gerard [36] demonstrated anatomical and physiological evidence of regeneration in the spinal cord through peripheral nerve grafts in 1940, though it was the work of Aguayo and colleagues that demonstrated a clear capacity for spinal cord regeneration through a peripheral graft using modern tracing methods $[37,38]$. These studies demonstrated that (for at least some cell populations) lesioned CNS neurons are capable of regeneration if the injured CNS is grafted with a substrate permissive to growth.

Within peripheral nerves, the principal cells are Schwann cells, which proliferate in response to injury [39]. Furthermore, the elimination of viable Schwann cells from peripheral nerve grafts abolishes the promotion of CNS regeneration [39-41]. Transplantation of Schwann cells into sites of CNS injury, including the lesioned spinal cord, mimics the effects of peripheral nerve grafts and supports axonal regeneration [42, 43]. In addition to potentially myelinating regenerated axons, Schwann cells express cell adhesion molecules, produce components of the extracellular matrix, and secrete multiple neurotrophic factors [4453]. Whether grafted Schwann cells provide an advantage in comparision with other potential cell grafts remains to be determined; however, as the grafted cells survive poorly in the lesioned spinal cord, they are soon replaced by migrating endogenous Schwann cells [54, 55]. 
Due to the multi-potent nature of neural stem cells and embryonic stem cells, these progenitors have been investigated for their potential in neural tissue replacement strategies and as neurotropic and neurotrophic substrates [56]. Neural stem cells secrete trophic cytokines and neurotrophins, and when transduced to over-express neurotrophic factors, exhibit enhanced neurotropic effects on spinal axons $[57,58]$. The diversity of studies using neural and embryonic stem cell transplantation after spinal cord injury is reviewed elsewhere (for more detail see Rossi and Keirstead [56]).

More readily accessible cell types available for autologous cell grafting include bone marrow stromal cells and ectoderm-derived fibroblasts. These cells can be noninvasively isolated from a patient, rapidly expanded in vitro, transduced to express therapeutic agents and transplanted without the need for immunosuppression. Numerous studies have used these non-neural cells as a means of bridging the lesion cavity, as well as providing extracellular matrix proteins and trophic support for regeneration [23, 59-68]. Although these cells are unable to initiate myelination of regenerated axons themselves, neurotrophin production by transplanted cells leads to robust graft infiltration by endogenous Schwann cells, which may act to promote or stabilize axonal regeneration in a secondary manner $[63,65,69,70]$.

\section{Neurotrophic Factors}

Neurotrophic factor expression is tightly linked to growth, maintenance of synapses, and survival of neurons during development. The first class of nervous system growth factors to be identified (the classic neurotrophin family) consists of nerve growth factor (NGF), brain-derived neurotrophic factor (BDNF), neurotrophin-3 (NT-3), and neurotrophin-4/5 [71]. Since the initial discovery of NGF more than 60 years ago, and the identification of the other neurotrophin family members in the 1980s and 1990s, several additional families of growth factors have been identified [72]. The most thoroughly studied growth factor family in models of SCI is the classic neurotrophin family, and the rest of this article will focus on these proteins. These neurotrophins have unique functions in the CNS and are differentially regulated during developmental maturation of the brain and spinal cord. All four neurotrophins are translated as proneurotrophins, which are subsequently proteolytically cleaved to produce $13 \mathrm{kD}$ proteins that exist as noncovalently linked homodimers [71]. All 4 can bind the low-affinity receptor $\mathrm{p} 75 \mathrm{NTR}$ (p75 neurotrophin receptor), which, when co-expressed with 1 of the high-affinity tropomyosin receptor kinase (trk) neurotrophin receptors, can modulate the signaling activity of trk [71].
Neurotrophin expression levels are regulated both spatially and temporally throughout development. NGF levels in the CNS decrease somewhat during postnatal development, but expression persists throughout adulthood in hippocampus, cortex, and olfactory bulb, which are all sites of neural plasticity in the adult [73]. BDNF levels exhibit a robust increase, primarily in the hippocampus where expression of both pro and mature forms peak perinatally before decreasing slightly to adult levels, whereas NT-3 expression levels decrease from neonates to adults, except in the hippocampus [73, 74]. In the adult spinal cord, there is a dramatic reduction in levels of NGF, BDNF, and NT-3 in comparison to embryonic expression levels [73].

\section{Neurotrophins, Development, and Survival}

The reduction in neurotrophin expression in the adult CNS is correlated with an apparently reduced requirement for trophic support, as well as a reduced potential for axonal plasticity. During development, availability of neurotrophins in the embryo and neonate govern the survival of neurons during a period of synaptic and neuronal elimination, with exogenously applied neurotrophins reducing normal levels of cell death [75]. The role of neurotrophins in preventing the inappropriate paring of synaptic connections in perinatal animals leaves these neurons much more susceptible to cell death following the removal of a trophic source, either through biochemical manipulations or via de-efferentation by axotomy, than neurons in adult animals $[76,77]$. Sciatic lesion in neonatal mice results in a loss of approximately two-thirds of the lower motor neurons in the lumbar enlargement, which is completely ameliorated with the application of BDNF, NT-3, or insulin-like growth factor I (IGF-I) [78]. This death of neonatal motor neurons is in stark contrast to lower motor neurons that not only survive, but regenerate following adult sciatic nerve injury; sciatic injury has been shown to result in increased NGF, BDNF, IGFs, cilliary neurotrophic factor, and glial-derived neurotrophic factor secretion from Schwann cells [44-53]. Antibody depletion of Schwann cell-produced BDNF leads to decreased regeneration and deficits in myelination of lower motor neurons and sensory neurons [79-81].

There are other nuclei in the adult CNS that maintain a requirement for trophic support as evidenced by somal atrophy or cell death following axotomy, although cell loss does not occur at the same rate or to the same extent as in neonatal animals. Axotomy of medial septal cholinergic neurons results in cell atrophy and eventual death that is ameliorated by NGF delivery within the first week [82-84]. Delayed NGF treatment cannot completely prevent cell loss, although it can restore cell size and neurotransmitter 
expression in a large proportion of medial septal cholinergic neurons [82, 83, 85].

Cortical and brainstem neurons involved in motor control pathways have demonstrated a somewhat reduced requirement for neurotrophic stimulation in the adult. During development, neonatal animals exhibit a critical period for axonal plasticity where lesioned and spared corticospinal, as well as rubrospinal motor axons may sprout following SCI [86-92]. Despite this capacity to sprout, the neurotrophic requirements of neonatal rubrospinal neurons lead to massive cell loss following rubrospinal tract lesion, which can be rescued with BDNF administration [91-93]. In contrast, rubrospinal tract lesion in the adult results in significant atrophy of motor neurons in the red nucleus but limited cell death; this atrophy is fully reversible with BDNF delivery even for as much as 1 year after SCI [94-97]. In addition, BDNF administration to either the red nucleus or the spinal cord following rubrospinal tract lesion results in up-regulation of growth associated genes and promotes axonal growth [67, 94-96, 98, 99].

Following adult SCI, corticospinal motor neurons exhibit somal atrophy but little if any cell loss; cortical atrophy can be prevented by BDNF administration to the spinal cord injury site $[100,101]$. Axotomy proximal to the cell body at the level of the internal capsule, however, results in a loss of approximately $50 \%$ of lesioned corticospinal motor neurons and atrophy of the surviving neurons [102]; this cell death and atrophy are completely prevented by high levels of BDNF or NT-3 treatment [23, 102, 103].

\section{Neurotrophins and Spinal Cord Regeneration}

Neurotrophin delivery to the injured spinal cord supports the growth of a number of discrete neuronal populations (Table 1). NGF promotes the sprouting and regeneration of cholinergic local motor axons, primary nociceptive sensory axons, and cerulospinal axons [104, 105]. BDNF-secreting bone marrow stromal cell grafts promote regeneration of a number of neuronal populations including raphaespinal, cerulospinal, rubrospinal, local motor and propprioceptive sensory axons $[63,67,94,96]$. NT-3 expression, similar to BDNF, promotes the regeneration of ascending sensory neurons across the dorsal root entry zone and within the dorsal columns [60, 64, 106-109].

Graded expression of NT-3 has been used to induce chemotropic regeneration of ascending sensory axons [60, 110]. In animals with low levels of NT-3 expression within a permissive dorsal column graft and higher levels in the spinal cord beyond the lesion, sensory axons are able to regenerate through the site of injury and reconstitute damaged neuronal circuitry (Fig. 1) [60,110]. Once sensory axons have re-entered host tissue, they can be guided to NT-
Table 1 Classic neurotrophins induce regeneration of distinct spinal cord axon populations

\begin{tabular}{|c|c|c|}
\hline $\begin{array}{l}\text { Growth } \\
\text { factor }\end{array}$ & $\begin{array}{l}\text { Central axon populations } \\
\text { affected }\end{array}$ & References \\
\hline \multirow[t]{2}{*}{ NGF } & $\begin{array}{l}\mathrm{ChAT}^{+} \text {motor } \\
\mathrm{CGRP}^{+} \text {sensory }\end{array}$ & \multirow[t]{2}{*}[62,104,105]{} \\
\hline & $\mathrm{TH}^{+}$coerulospinal & \\
\hline \multirow[t]{3}{*}{ BDNF } & $\begin{array}{l}\text { 5- } \mathrm{HT}^{+} \text {raphaespinal } \\
\mathrm{TH}^{+} \text {coerulospinal }\end{array}$ & \multirow[t]{3}{*}[63,67,94,96,112]{} \\
\hline & $\mathrm{NF}^{2} 20^{+}$proprioceptive sensory & \\
\hline & Rubrospinal & \\
\hline \multirow[t]{2}{*}{ NT-3 } & $\begin{array}{l}5-\mathrm{HT}^{+} \text {raphaespinal } \\
\mathrm{NF} 200^{+} \text {proprioceptive sensory }\end{array}$ & \multirow[t]{2}{*}[60,61,64,106-113]{} \\
\hline & $\begin{array}{l}\text { Corticospinal motor (axon } \\
\text { plasticity only) }\end{array}$ & \\
\hline NT-4 & $\begin{array}{l}\text { 5- } \mathrm{HT}^{+} \text {raphaespinal } \\
\mathrm{TH}^{+} \text {coerulospinal }\end{array}$ & {$[112]$} \\
\hline
\end{tabular}

$\mathrm{BDNF}=$ brain-derived neurotrophic factor; $\mathrm{NGF}=$ nerve growth factor; NT-3 = neurotrophin-3; NT-4 = neurotrophin-4; 5 -HT ${ }^{+}=$(serotonergic) raphaespinal; $\mathrm{TH}^{+}$(tyrosine hydroxylase expressing) coerulospinal

3-secreting nuclei several millimeters away and form synapses on neurons in the appropriate target nucleus [110]. These synapses in nucleus gracilis are indistinguishable from intact synapses at the ultrastructural level, containing clusters of synaptic vesicles. However, the newly formed regenerated projections are not electrophysiologically active, possibly due in part to a failure of remyelination [110].

Provision of growth factor gradients can promote regeneration, even at chronic time periods after injury. When treatment with NT-3 is delayed as much as 15 months after SCI, dorsal column proprioceptive axons are able to initiate a regenerative response and bridge into, and beyond, cell grafts placed in the chronic lesion site [111]. This regeneration of chronically injured neurons is possible only when coupled with modulation of the intrinsic growth state by peripheral conditioning lesion (discussed in detail as follows) [111].

\section{Intrinsic Capacity to Regenerate}

Sensory neurons in the dorsal root ganglia demonstrate a robust change in regenerative potential of the central axon in the spinal cord following a "conditioning" crush lesion of the peripheral branch of the neuron $[114,115]$. This increase in regenerative potential of the neuron is accompanied by regulated changes in thousands of genes in the dorsal root ganglia [47, 116]. Collectively, these changes in transcriptional programs represent a change in the intrinsic regenerative state of the neuron. Among the many changes activated by a conditioning lesion are increases in BDNF 

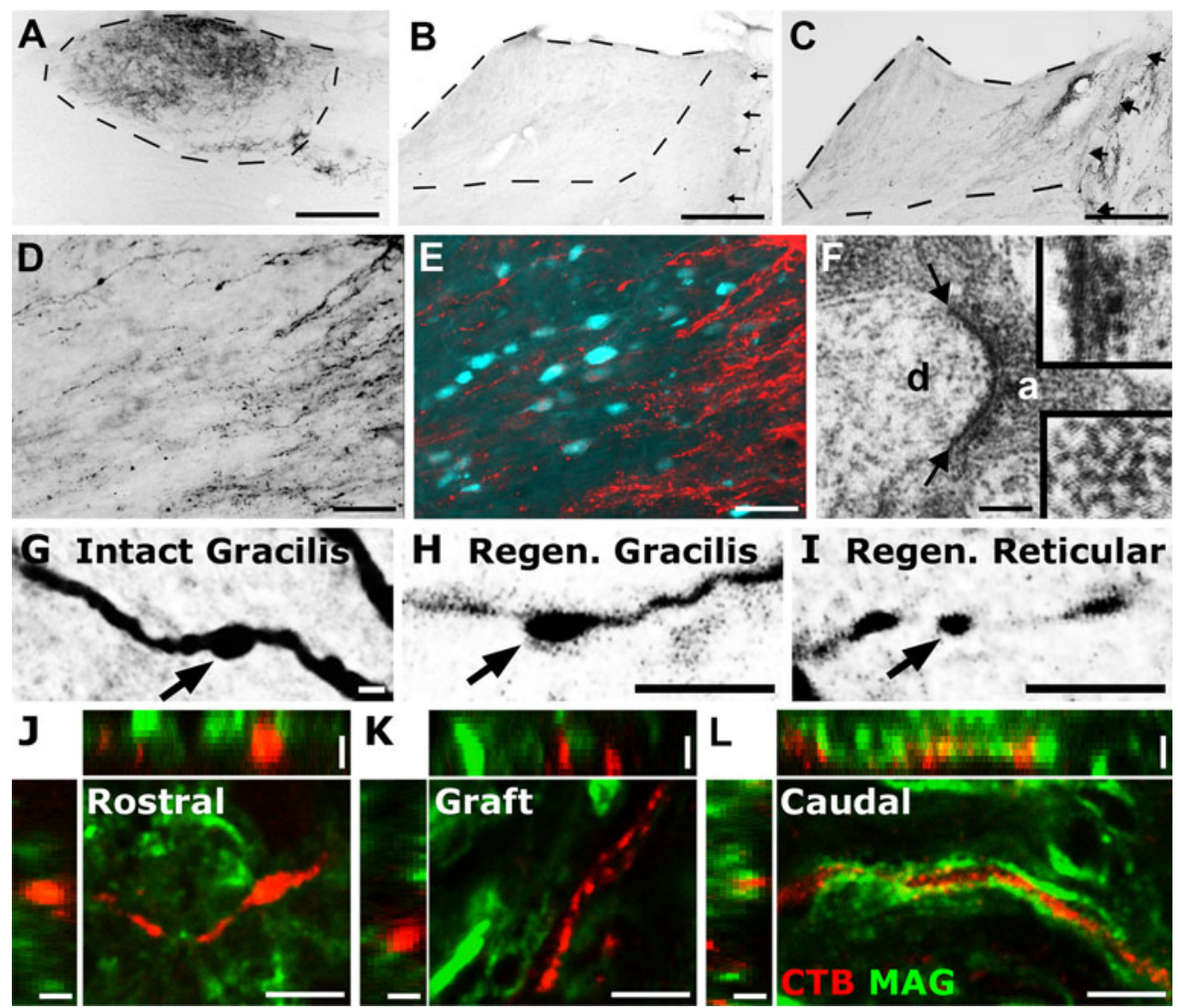

Fig. 1 Expression of neurotrophin-3 (NT-3) gradients can induce sensory regeneration and synapse formation in target nuclei. (a) The transganglionic tracer cholera toxin B subunit (CTB) labels ascending sensory neurons in nucleus gracilis in an intact animal. (b) Control animals receiving green fluorescent protein (GFP) expressing lentivirus in the nucleus gracilis do not exhibit axonal regeneration into the nucleus. (c) NT-3 expression in nucleus gracilis, as well as the lesion site facilitates reinnervation of the appropriate target nucleus. (d, e) CTB-labeled sensory axons approach secondary sensory neurons in nucleus gracilis (labeled retrogradely by flourogold injection to the ventro-posterolateral nucleus of the thalamus). (f) Electron microscopy reveals pre-synaptic structures (between arrows) in regenerated, CTB- labeled sensory axons (a) in nucleus gracilis on a dendritic process (d) with asymmetric synaptic specializations (top inset) with CTB surrounded by electron-dense synaptic vesicles (bottom inset). (g-i) Axons in intact (g), re-innervated target nucleus gracilis (h), and newly innervated nontarget areas (reticular formation); (i) labeled with CTB display bouton-like structures resembling synapses. (j-l) Despite reinnervation of target nuclei, regenerated axons are not electrophysiologically active and lack remyelination both in and beyond grafted NT-3 secreting more readily accessible cell types available for autologous cell grafting, include bone marrow stromal cells 1 month after central injury. Scale bars $250 \mu \mathrm{m}$ (A-C), $50 \mu \mathrm{m}$ (D, E), $0.4 \mu \mathrm{m}$ (F), $5 \mu \mathrm{m}$ (G-I), (J-L) main panels), and $2.5 \mu \mathrm{m}(\mathrm{J}-\mathrm{L}) \mathrm{z}$-stack side panels expression. Indeed, blockade of BDNF both in vivo and in neuronal cultures attenuates neurite outgrowth after conditioning lesions $[80,81]$. Priming dorsal root ganglia with neurotrophins in vitro results in elevated cyclic adenosine monophosphate (cAMP) levels and protein kinase A (PKA) activation, which similar to conditioning lesion attenuates the neurite outgrowth-inhibitory effects of central myelin [117]. Similarly, conditioning lesions elevate cAMP levels in dorsal root ganglia [118], and conditioning effects can be partly replicated by cAMP injections into dorsal root ganglia (DRG) neurons [118, 119].

Developmental down-regulation of growth-associated genes is a potential reason for the lack of regeneration in the adult CNS. GAP-43 is highly expressed in the embryonic and early postnatal spinal cord with almost undetectable levels by P29 [120]. Following peripheral conditioning lesions, lower motor neurons and dorsal root ganglia sensory neurons dramatically upregulate GAP-43 mRNA and levels remain elevated for 5 to 10 weeks [121]. This increase in GAP-43 expression does not occur following lesion of the central branch of dorsal root ganglia sensory neurons, suggesting a potential role for GAP-43 in the regenerative response, which occurs specifically following peripheral lesion [122].

Electrical stimulation of lesioned femoral nerve promotes regeneration of lower motor neurons [123, 124]. Brief stimulation of lesioned femoral nerves for 1 hour leads to a rapid increase in messenger RNA (mRNA) levels of BDNF and its complementary high affinity receptor trkB in the motor neurons that peaks 2 days poststimulation with maximum sixfold and fourfold increases, respectively, in comparison to contralateral intact motor neurons [25]. 
Temporally following increases in BDNF and trkB expression is an increase in mRNA of the growth-associated genes T $\alpha 1$-tubulin (Talpha1-tubulin) and GAP-43 [26]. Interestingly, electrical stimulation of the intact sciatic nerve for $1 \mathrm{~h}$ increases cAMP levels in the dorsal root ganglia to levels found $24 \mathrm{~h}$ following sciatic nerve conditioning lesion [125]. Similar to cAMP elevation via direct injection of the membrane-permeable analog db-cAMP, electrical stimulation of the sciatic nerve also promotes significant sensory axonal regeneration both in cultured dissociated adult dorsal root ganglia neurons and in vivo following a central lesion [125]. Electrical stimulation may therefore activate a similar cascade of events as peripheral conditioning lesions, and could potentially be used to promote regeneration.

Although peripheral conditioning promotes regeneration of sensory neurons through modulation of intrinsic signaling pathways, there is no correlate mechanism for stimulating regeneration of central motor pathways. Corticospinal motor neurons are perhaps the most refractory of neuronal systems in response to therapeutic intervention following injury. Corticospinal neurons extend axons in response to IGF-I during development; however, in the adult IGF-I has no effect on corticospinal axons potentially due to a combination of a lack of receptor trafficking to the axon and a developmental increase in expression of the inhibitory IGFbinding proteins [24, 126, 127]. NT-3 promotes sprouting of corticospinal axons into gray matter surrounding spinal cord lesion sites, but these axons do not regenerate into cell grafts placed into lesion sites [61, 113, 128, 129].

As the corticospinal motor neurons cannot be conditioned to regenerate, alternative means must be used to enhance their intrinsic growth state. Viral delivery has been used to deliver integrin receptors and retinoic acid receptors to sensory neurons to enhance axonal growth from the transduced neurons $[130,131]$. These studies focused on manipulation of the cellular response in neurons that are already able to regenerate; however, a similar approach has also been used to alter the response of the more refractory corticospinal motor neurons. Viral delivery of the high affinity BDNF neurotrophin receptor trkB to the motor cortex, resulting in over-expression of trkB, can alter the response of cortical neurons and corticospinal motor neurons in particular to BDNF-secreting grafts [132]. Over-expressed trkB is trafficked into the axonal compartment of identified corticospinal neurons and results in regeneration of transduced neurons into subcortical BDNFsecreting grafts through Erk/Map kinase pathways [132]. Trafficking of the receptor is limited, however, as virally expressed trkB is undetectable in the spinal cord [132]. One of the downstream mediators of neurotrophin signaling is phosphoinositide 3-kinase, which signals through the serinethreonine kinase Akt, a process inhibited by phosphotase and tensin homologue (PTEN) [133-135]. Mice lacking PTEN are able to regenerate axons following optic nerve crush and exhibit sprouting of corticospinal axons after injury, similar to observations after NT-3 delivery to the injured spinal cord $[136,137]$. Studies with NT-3 and PTEN underscore that attempts to promote corticospinal regeneration may require not only modulation of the injured environment, but also the intrinsic growth state of injured neurons $[132,136]$.

\section{Translation of Pre-Clinical Rodent Studies to Potential Therapies}

The vast majority of pre-clinical research undertaken on spinal cord injury is performed in mice and rats. One of the key steps in translating these therapies to the clinic will be to understand the response of motor and sensory systems to injury in primate species. Perhaps the most crucial example of interspecies variation in function and response to injury is the corticospinal tract. Regeneration of the corticospinal system is of crucial importance for the restoration of voluntary motor function after injury in both human and nonhuman primates, whereas rodents are capable of driving a broad repertoire of motor activities completely independent of a functional corticospinal circuit [138]. Recently, it has been demonstrated that some of the spontaneous functional recovery seen after injury in humans may have a correlate in nonhuman primates at both the behavioral level, and perhaps more significantly at the neuroanatomical level, at which the primate corticospinal tract exhibits remarkable spontaneous sprouting after incomplete SCI [10]. As in rodents, neurotrophins can reduce atrophy of corticospinal neurons following injury in nonhuman primates, yet it remains to be seen whether neurotrophins can enhance the endogenous plasticity of corticospinal axons in primates [101].

As with any potential therapy, the off-target effects of neurotrophin treatment must be considered. Intracerebroventricular infusion of NGF to treat Alzheimer's disease was halted in a trial of 3 individuals due to the induction of pain and weight loss during the course of treatment [139]. In this case, the induction of neuropathic pain and the effects on the hypothalamus were consistent with the preclinical literature on intracerebroventricular infusion of NGF [140]. Many of the off-target effects of neurotrophin treatment can be avoided through targeted delivery of neurotrophins through ex vivo cell therapy or localized expression by viral transduction, as used in many of the studies previously described [140].

\section{Conclusion}

Neurotrophins have been used to both induce axon growth and prevent atrophy and death of a number of distinct 
neuronal populations after adult SCI. Cellular responses to neurotrophin stimulation likely depend on the intrinsic modulation of receptor expression and trafficking, as well as control of growth-associated genetic programs. As these responses change, along with the maturation of the nervous system, an understanding of the associated developmental changes may lead to future strategies to promote functional regeneration. Importantly, injury studies have shown discrepancies in the response to SCI between rodents and primates; this demonstrates that in some cases successful translation of regeneration strategies may be optimized by primate or other larger animal studies. Administration of growth factors is likely to constitute an important component of future combinatorial treatment strategies for SCI.

Acknowledgements This work was supported by the NIH, the Veterans Administration, the Dr. Miriam and Sheldon G. Adelson Medical Research Foundation, and the Bernard and Anne Spitzer Charitable Trust (M.H.T.). Financial support is also received from the Craig H. Neilsen Foundation (E.R.H.).

Full conflict of interest disclosures is available in the electronic supplementary material for this article.

\section{References}

1. Jackson AB, Dijkers M, DeVivo MJ, Poczatek RB. A demographic profile of new traumatic spinal cord injuries: change and stability over 30 years. Arch Phys Med Rehabil 2004;85:1740-1748.

2. Fawcett JW, Curt A, Steeves JD, et al. Guidelines for the conduct of clinical trials for spinal cord injury as developed by the ICCP panel: spontaneous recovery after spinal cord injury and statistical power needed for therapeutic clinical trials. Spinal Cord 2006;45:190-205.

3. Basso DM, Beattie MS, Bresnahan JC. Graded histological and locomotor outcomes after spinal cord contusion using the NYU weight-drop device versus transection. Exp Neurol 1996;139:244 256.

4. Bishop B. Neural plasticity, part 4. Lesion-induced reorganization of the CNS: recovery phenomena. Phys Ther 1982;62:14421451.

5. Little JW, Ditunno JF, Stiens SA, Harris RM. Incomplete spinal cord injury: Neuronal mechanisms of motor recovery and hyperreflexia. Arch Phys Med Rehabil 1999;80:587-599.

6. Darian-Smith C, Brown S. Functional changes at periphery and cortex following dorsal root lesions in adult monkeys. Nat Neurosci 2000;3:476-481.

7. Jurkiewicz MT, Mikulis DJ, Fehlings MG, Verrier MC. Sensorimotor cortical activation in patients with cervical spinal cord injury with persisting paralysis. Neurorehabil Neural Repair 2010;24:136-140.

8. Jurkiewicz MT, Mikulis DJ, McIlroy WE, Fehlings MG, Verrier MC. Sensorimotor cortical plasticity during recovery following spinal cord injury: a longitudinal fMRI study. Neurorehabil Neural Repair 2007;21:527-538.

9. Mikulis DJ, Jurkiewicz MT, McIlroy WE, et al. Adaptation in the motor cortex following cervical spinal cord injury. Neurology 2002;58:794-801.

10. Rosenzweig ES, Courtine G, Jindrich DL, et al. Extensive spontaneous plasticity of corticospinal projections after primate spinal cord injury. Nat Neurosci 2010;13:1505-1510.
11. Hurlbert RJ. Strategies of medical intervention in the management of acute spinal cord injury. Spine 2006;31:S16-S36.

12. Fehlings MG, Baptiste DC. Current status of clinical trials for acute spinal cord injury. Injury 2005;36:S113-S122.

13. Fehlings MG, Perrin RG. The timing of surgical intervention in the treatment of spinal cord injury: a systematic review of recent clinical evidence. Spine 2006;31:S28-S35.

14. Levi L, Wolf A, Belzberg H. Hemodynamic parameters in patients with acute cervical cord trauma: description, intervention, and prediction of outcome. Neurosurgery 1993;33:10071016.

15. Levi L, Wolf A, Rigamonti D, Ragheb J, Mirvis S, Robinson WL. Anterior decompression in cervical spine trauma: does the timing of surgery affect the outcome? Neurosurgery 1991;29:216222.

16. Tator CH, Rowed DW, Schwartz ML, et al. Management of acute spinal cord injuries. Can J Surg 1984;27:289-296.

17. Vale FL, Burns J, Jackson AB, Hadley MN. Combined medical and surgical treatment after acute spinal cord injury: results of a prospective pilot study to assess the merits of aggressive medical resuscitation and blood pressure management. J Neurosurg 1997;87:239-246.

18. Zach GA, Seiler W, Dollfus P. Treatment results of spinal cord injuries in the Swiss Parplegic Centre of Basle. Paraplegia $1976 ; 14: 58-65$

19. Levi AD, Casella G, Green BA, et al. Clinical outcomes using modest intravascular hypothermia after acute cervical spinal cord injury. Neurosurgery 2010;66:670-677.

20. Levi AD, Green BA, Wang MY, et al. Clinical application of modest hypothermia after spinal cord injury. J Neurotrauma 2009;26:407-415.

21. Thuret S, Moon LDF, Gage FH. Therapeutic interventions after spinal cord injury. Nat Rev Neurosci 2006;7:628-643.

22. Hiebert GW, Dyer JK, Tetzlaff W, Steeves JD. Immunological myelin disruption does not alter expression of regenerationassociated genes in intact or axotomized rubrospinal neurons. Exp Neurol 2000;163:149-156.

23. Lu P, Blesch A, Tuszynski MH. Neurotrophism without neurotropism: BDNF promotes survival but not growth of lesioned corticospinal neurons. J Comp Neurol 2001;436:456-470.

24. Arlotta P, Molyneaux BJ, Chen J, Inoue J, Kominami R, Macklis JD. Neuronal subtype-specific genes that control corticospinal motor neuron development in vivo. Neuron 2005;45:207-221.

25. Al-Majed AA, Brushart TM, Gordon T. Electrical stimulation accelerates and increases expression of BDNF and trkB mRNA in regenerating rat femoral motoneurons. European Journal of Neuroscience 2000;12:4381-4390.

26. Al-Majed AA, Tam SL, Gordon T. Electrical stimulation accelerates and enhances expression of regeneration-associated genes in regenerating rat femoral motoneurons. Cell Mol Neurobiol 2004;24:379-402.

27. Ramer LM, Ramer MS, Steeves JD. Setting the stage for functional repair of spinal cord injuries: a cast of thousands. Spinal Cord 2005;43:134-161.

28. Schwab ME, Bartholdi D. Degeneration and regeneration of axons in the lesioned spinal cord. Physiol Rev 1996;76:319-370.

29. Filbin MT. Myelin-associated inhibitors of axonal regeneration in the adult mammalian CNS. Nat Rev Neurosci 2003;4:703-713.

30. Silver J, Miller JH. Regeneration beyond the glial scar. Nat Rev Neurosci 2004;5:146-156.

31. Löw K, Culbertson M, Bradke F, Tessier-Lavigne M, Tuszynski MH. Netrin-1 Is a Novel Myelin-Associated Inhibitor to Axon Growth. J Neurosci 2008;28:1099-1108.

32. Liu Y, Wang X, Lu CC, et al. Repulsive Wnt signaling inhibits axon regeneration after CNS injury. J Neurosci 2008;28:83768382 . 
33. Pasterkamp RJ, Verhaagen J. Semaphorins in axon regeneration: developmental guidance molecules gone wrong? Philos Trans R Soc Lond B Biol Sci 2006;361:1499-1511.

34. Benowitz L, Yin Y. Rewiring the injured CNS: lessons from the optic nerve. Exp Neurol 2008;209:389-398.

35. Ramón y Cdajal S. Cajal's Degeneration and regeneration of the nervous system. New York: Oxford University Press, 1991.

36. Sugar O, Gerard RW. Spinal cord regeneration in the rat. J Neurophysiol 1940;3:1-19.

37. David S, Aguayo AJ. Axonal elongation into peripheral nervous system "bridges" after central nervous system injury in adult rats. Science 1981;214:931-933.

38. Richardson PM, McGuinness UM, Aguayo AJ. Axons from CNS neurones regenerate into PNS grafts. Nature 1980;284:264265.

39. Fawcett JW, Keynes RJ. Peripheral nerve regeneration. Annu Rev Neurosci 1990;13:43-60.

40. Berry M, Hall S, Follows R, Rees L, Gregson N, Sievers J. Response of axons and glia at the site of anastomosis between the optic nerve and cellular or acellular sciatic nerve grafts. J Neurocytol 1988;17:727-744.

41. Berry M, Rees L, Hall S, Yiu P, Sievers J. Optic axons regenerate into sciatic nerve isografts only in the presence of Schwann cells. Brain Res Bull 1988;20:223-231.

42. Kromer LF, Cornbrooks CJ. Transplants of Schwann cell cultures promote axonal regeneration in the adult mammalian brain. Proc Natl Acad Sci U S A 1985;82:6330-6334.

43. Paino CL, Bunge MB. Induction of axon growth into Schwann cell implants grafted into lesioned adult rat spinal cord. Exp Neurol 1991;114:254-257.

44. Bunge RP. The role of the Schwann cell in trophic support and regeneration. J Neurol 1994;242:S19-S21.

45. Meyer M, Matsuoka I, Wetmore C, Olson L, Thoenen H. Enhanced synthesis of brain-derived neurotrophic factor in the lesioned peripheral nerve: different mechanisms are responsible for the regulation of BDNF and NGF mRNA. J Cell Biol 1992;119:45-54.

46. Sendtner M, Holtmann B, Kolbeck R, Thoenen H, Barde YA. Brainderived neurotrophic factor prevents the death of motoneurons in newborn rats after nerve section. Nature 1992;360:757-759.

47. Costigan M, Befort K, Karchewski L, et al. Replicate highdensity rat genome oligonucleotide microarrays reveal hundreds of regulated genes in the dorsal root ganglion after peripheral nerve injury. BMC Neurosci 2002;3:16.

48. Curtis R, Adryan KM, Zhu Y, Harkness PJ, Lindsay RM, DiStefano PS. Retrograde axonal transport of ciliary neurotrophic factor is increased by peripheral nerve injury. Nature 1993;365:253-255.

49. Höke A, Cheng C, Zochodne DW. Expression of glial cell linederived neurotrophic factor family of growth factors in peripheral nerve injury in rats. Neuroreport 2000;11:1651-1654.

50. Naveilhan P, ElShamy WM, Ernfors P. Differential regulation of mRNAs for GDNF and its receptors Ret and GDNFR alpha after sciatic nerve lesion in the mouse. Eur J Neurosci 1997;9:1450 1460.

51. Shen H, Chung JM, Chung K. Expression of neurotrophin mRNAs in the dorsal root ganglion after spinal nerve injury. Mol Brain Res 1999;64:186-192.

52. Funakoshi H, Frisen J, Barbany G, et al. Differential expression of mRNAs for neurotrophins and their receptors after axotomy of the sciatic nerve. J Cell Biol 1993;123:455-465.

53. Glazner GW, Morrison AE, Ishii DN. Elevated insulin-like growth factor (IGF) gene expression in sciatic nerves during IGF-supported nerve regeneration. Mol Brain Res 1994;25:265272.
54. Barakat DJ, Gaglani SM, Neravetla SR, et al. Survival, integration, and axon growth support of glia transplanted into the chronically contused spinal cord. Cell Transplant 2005;14:225-240.

55. Pearse DD, Sanchez AR, Pereira FC, et al. Transplantation of Schwann cells and/or olfactory ensheathing glia into the contused spinal cord: survival, migration, axon association, and functional recovery. Glia 2007;55:976-1000.

56. Rossi SL, Keirstead HS. Stem cells and spinal cord regeneration. Curr Opin Biotechnol 2009;20:552-562.

57. Lu P, Jones LL, Snyder EY, Tuszynski MH. Neural stem cells constitutively secrete neurotrophic factors and promote extensive host axonal growth after spinal cord injury. Exp Neurol 2003;181:115-129.

58. Yan J, Welsh AM, Bora SH, Snyder EY, Koliatsos VE. Differentiation and tropic/trophic effects of exogenous neural precursors in the adult spinal cord. J Comp Neurol 2004;480:101114.

59. Senut MC, Tuszynski MH, Raymon HK, et al. Regional differences in responsiveness of adult CNS axons to grafts of cells expressing human neurotrophin 3. Exp Neurol 1995;135:36-55.

60. Taylor L, Jones L, Tuszynski MH, Blesch A. Neurotrophin-3 gradients established by lentiviral gene delivery promote shortdistance axonal bridging beyond cellular grafts in the injured spinal cord. J Neurosci 2006;26:9713-9721.

61. Tuszynski MH, Grill R, Jones LL, et al. NT-3 gene delivery elicits growth of chronically injured corticospinal axons and modestly improves functional deficits after chronic scar resection. Exp Neurol 2003;181:47-56.

62. Tuszynski MH, Peterson DA, Ray J, Baird A, Nakahara Y, Gage FH. Fibroblasts genetically modified to produce nerve growth factor induce robust neuritic ingrowth after grafting to the spinal cord. Exp Neurol 1994;126:1-14.

63. Lu P, Jones LL, Tuszynski MH. BDNF-expressing marrow stromal cells support extensive axonal growth at sites of spinal cord injury. Exp Neurol 2005;191:344-360.

64. Lu P, Yang H, Jones LL, Filbin MT, Tuszynski MH. Combinatorial therapy with neurotrophins and cAMP promotes axonal regeneration beyond sites of spinal cord injury. J Neurosci 2004;24:6402-6409.

65. Jones LL, Sajed D, Tuszynski MH. Axonal regeneration through regions of chondroitin sulfate proteoglycan deposition after spinal cord injury: a balance of permissiveness and inhibition. $\mathrm{J}$ Neurosci 2003;23:9276-9288.

66. Blesch A, Tuszynski MH. GDNF gene delivery to injured adult CNS motor neurons promotes axonal growth, expression of the trophic neuropeptide CGRP, and cellular protection. J Comp Neurol 2001;436:399-410.

67. Liu Y, Kim D, Himes BT, et al. Transplants of fibroblasts genetically modified to express BDNF promote regeneration of adult rat rubrospinal axons and recovery of forelimb function. $\mathrm{J}$ Neurosci 1999;19:4370-4387.

68. Hofstetter CP, Schwarz EJ, Hess D, et al. Marrow stromal cells form guiding strands in the injured spinal cord and promote recovery. Proc Natl Acad Sci U S A 2002;99:2199-2204.

69. Blesch A, Tuszynski MH. Transient growth factor delivery sustains regenerated axons after spinal cord injury. J Neurosci 2007;27:10535-10545.

70. Blesch A, Yang H, Weidner N, Hoang A, Otero D. Axonal responses to cellularly delivered NT-4/5 after spinal cord injury. Mol Cell Neurosci 2004;27:190-201.

71. Bibel M, Barde YA. Neurotrophins: key regulators of cell fate and cell shape in the vertebrate nervous system. Genes Dev 2000;14:2919-2937. 
72. Johnson Jr EM, Tuszynski MH. Neurotrophic factors. In: Jeffrey HK, Mark HT, eds. CNS regeneration, 2nd edit. San Diego: Academic Press, 2008:95-144.

73. Maisonpierre PC, Belluscio L, Friedman B, et al. NT-3, BDNF, and NGF in the developing rat nervous system: parallel as well as reciprocal patterns of expression. Neuron 1990;5:501-509.

74. Yang J, Siao C-J, Nagappan G, et al. Neuronal release of proBDNF. Nat Neurosci 2009;12:113-115.

75. Oppenheim RW, Yin QW, Prevette D, Yan Q. Brain-derived neurotrophic factor rescues developing avian motoneurons from cell death. Nature 1992;360:755-757.

76. Thoenen H, Barde YA. Physiology of nerve growth factor. Physiol Rev 1980;60:1284-1335.

77. Snider WD, Johnson EM, Jr. Neurotrophic molecules. Ann Neurol 1989;26:489-506.

78. Li L, Oppenheim RW, Lei M, Houenou LJ. Neurotrophic agents prevent motoneuron death following sciatic nerve section in the neonatal mouse. J Neurobiol 1994;25:759-766.

79. Zhang J-Y, Luo X-G, Xian CJ, Liu Z-H, Zhou X-F. Endogenous $\mathrm{BDNF}$ is required for myelination and regeneration of injured sciatic nerve in rodents. Eur J Neurosci 2000;12:4171-4180.

80. Geremia NM, Pettersson LME, Hasmatali JC, et al. Endogenous $\mathrm{BDNF}$ regulates induction of intrinsic neuronal growth programs in injured sensory neurons. Exp Neurol 2010;223:128-142.

81. Song XY, Li F, Zhang FH, Zhong JH, Zhou XF. Peripherallyderived BDNF promotes regeneration of ascending sensory neurons after spinal cord injury. PLoS ONE 2008;3:e1707.

82. Hagg T, Fass-Holmes B, Vahlsing HL, Manthorpe M, Conner JM, Varon S. Nerve growth factor (NGF) reverses axotomyinduced decreases in choline acetyltransferase, NGF receptor and size of medial septum cholinergic neurons. Brain Res 1989;505:29-38.

83. Hagg T, Manthorpe M, Vahlsing HL, Varon S. Delayed treatment with nerve growth factor reverses the apparent loss of cholinergic neurons after acute brain damage. Exp Neurol 1988;101:303312.

84. Hefti F. Nerve growth factor promotes survival of septal cholinergic neurons after fimbrial transections. J Neurosci 1986;6:2155-2162.

85. Fischer W, Björklund A. Loss of AChE- and NGFr-labeling precedes neuronal death of axotomized septal-diagonal band neurons: Reversal by intraventricular NGF infusion. Exp Neurol 1991;113:93-108.

86. Bates CA, Stelzner DJ. Extension and regeneration of corticospinal axons after early spinal injury and the maintenance of corticospinal topography. Exp Neurol 1993;123:106-117.

87. Bernstein DR, Stelzner DJ. Plasticity of the corticospinal tract following midthoracic spinal injury in the postnatal rat. J Comp Neurol 1983;221:382-400.

88. Firkins SS, Bates CA, Stelzner DJ. Corticospinal tract plasticity and astroglial reactivity after cervical spinal injury in the postnatal rat. Exp Neurol 1993;120:1-15.

89. Kalil K, Reh T. A light and electron microscopic study of regrowing pyramidal tract fibers. J Comp Neurol 1982;211:265275.

90. Reh T, Kalil K. Functional role of regrowing pyramidal tract fibers. J Comp Neurol 1982;211:276-283.

91. Bregman BS, Goldberger ME. Anatomical plasticity and sparing of function after spinal cord damage in neonatal cats. Science 1982;217:553-555.

92. Xu XM, Martin GF. The response of rubrospinal neurons to axotomy at different stages of development in the North American opossum. J Neurotrauma 1992;9:93-105.

93. Wang XM, Terman JR, Martin GF. Rescue of axotomized rubrospinal neurons by brain-derived neurotrophic factor
(BDNF) in the developing opossum, Didelphis virginiana. Dev Brain Res 1999;118:177-184.

94. Kobayashi NR, Fan D-P, Giehl KM, Bedard AM, Wiegand SJ, Tetzlaff W. BDNF and NT-4/5 prevent atrophy of rat rubrospinal neurons after cervical axotomy, stimulate GAP-43 and talpha 1tubulin mRNA Expression, and promote axonal regeneration. $\mathrm{J}$ Neurosci 1997;17:9583-9595.

95. Kwon BK, Liu J, Lam C, et al. Brain-derived neurotrophic factor gene transfer with adeno-associated viral and lentiviral vectors prevents rubrospinal neuronal atrophy and stimulates regeneration-associated gene expression after acute cervical spinal cord injury. Spine 2007;32:1164-1173.

96. Kwon BK, Liu J, Messerer C, et al. Survival and regeneration of rubrospinal neurons 1 year after spinal cord injury. Proc Natl Acad Sci U S A 2002;99:3246-3251.

97. Liu Y, Himes BT, Murray M, Tessler A, Fischer I. Grafts of BDNF-producing fibroblasts rescue axotomized rubrospinal neurons and prevent their atrophy. Exp Neurol 2002;178:150 164.

98. Ruitenberg MJ, Plant GW, Hamers FP, et al. Ex vivo adenoviral vector-mediated neurotrophin gene transfer to olfactory ensheathing glia: effects on rubrospinal tract regeneration, lesion size, and functional recovery after implantation in the injured rat spinal cord. J Neurosci 2003;23:7045-7058.

99. Tobias CA, Shumsky JS, Shibata M, et al. Delayed grafting of BDNF and NT-3 producing fibroblasts into the injured spinal cord stimulates sprouting, partially rescues axotomized red nucleus neurons from loss and atrophy, and provides limited regeneration. Exp Neurol 2003;184:97-113.

100. Tang XQ, Wang Y, Huang ZH, Han JS, Wan Y. Adenovirusmediated delivery of GDNF ameliorates corticospinal neuronal atrophy and motor function deficits in rats with spinal cord injury. Neuroreport 2004;15:425-429.

101. Brock JH, Rosenzweig ES, Blesch A, et al. Local and Remote Growth Factor Effects after Primate Spinal Cord Injury. J Neurosci 2010;30:9728-9737.

102. Giehl KM, Tetzlaff W. BDNF and NT-3, but not NGF, prevent axotomy-induced death of rat corticospinal neurons in vivo. Eur J Neurosci 1996;8:1167-1175.

103. Giehl KM, Rohrig S, Bonatz H, et al. Endogenous brain-derived neurotrophic factor and neurotrophin-3 antagonistically regulate survival of axotomized corticospinal neurons in vivo. J Neurosci 2001;21:3492-3502.

104. Grill RJ, Blesch A, Tuszynski MH. Robust growth of chronically injured spinal cord axons induced by grafts of genetically modified NGF-secreting cells. Exp Neurol 1997;148:444-452.

105. Tuszynski MH, Gabriel K, Gage FH, Suhr S, Meyer S, Rosetti A. Nerve growth factor delivery by gene transfer induces differential outgrowth of sensory, motor, and noradrenergic neurites after adult spinal cord injury. Exp Neurol 1996;137:157-173.

106. Bradbury EJ, Khemani S, Von R, King, Priestley JV, McMahon SB. NT-3 promotes growth of lesioned adult rat sensory axons ascending in the dorsal columns of the spinal cord. Eur J Neurosci 1999;11:3873-3883.

107. Ramer MS, Priestley JV, McMahon SB. Functional regeneration of sensory axons into the adult spinal cord. Nature 2000;403:312-316.

108. Zhang Y, Dijkhuizen PA, Anderson PN, Lieberman AR, Verhaagen J. NT-3 delivered by an adenoviral vector induces injured dorsal root axons to regenerate into the spinal cord of adult rats. J Neurosci Res 1998;54:554-562.

109. Oudega M, Hagg T. Neurotrophins promote regeneration of sensory axons in the adult rat spinal cord. Brain Res 1999;818:431-438. 
110. Alto LT, Havton LA, Conner J, Hollis II ER, Blesch A, Tuszynski $\mathrm{MH}$. Chemotropic guidance facilitates axonal regeneration into brainstem targets and synapse formation after spinal cord injury. Nat Neurosci 2009;12:1106-1113.

111. Kadoya K, Tsukada S, Lu P, et al. Combined intrinsic and extrinsic neuronal mechanisms facilitate bridging axonal regeneration one year after spinal cord injury. Neuron 2009;64:165172.

112. Bregman BS, McAtee M, Dai HN, Kuhn PL. Neurotrophic factors increase axonal growth after spinal cord injury and transplantation in the adult rat. Exp Neurol 1997;148:475-494.

113. Grill R, Murai K, Blesch A, Gage FH, Tuszynski MH. Cellular delivery of neurotrophin-3 promotes corticospinal axonal growth and partial functional recovery after spinal cord injury. J Neurosci 1997; 17:5560-5572.

114. Richardson PM, Issa VM. Peripheral injury enhances central regeneration of primary sensory neurones. Nature 1984;309:791793.

115. Neumann S, Woolf CJ. Regeneration of dorsal column fibers into and beyond the lesion site following adult spinal cord injury. Neuron 1999;23:83-91.

116. Stam FJ, MacGillavry HD, Armstrong NJ, et al. Identification of candidate transcriptional modulators involved in successful regeneration after nerve injury. Eur J Neurosci 2007;25:36293637.

117. Cai D, Shen Y, De Bellard M, Tang S, Filbin MT. Prior exposure to neurotrophins blocks inhibition of axonal regeneration by MAG and myelin via a cAMP-dependent mechanism. Neuron 1999;22:89-101.

118. Qiu J, Cai D, Dai H, et al. Spinal axon regeneration induced by elevation of cyclic AMP. Neuron 2002;34:895-903.

119. Neumann S, Bradke F, Tessier-Lavigne M, Basbaum AI. Regeneration of sensory axons within the injured spinal cord induced by intraganglionic cAMP elevation. Neuron 2002;34:885893.

120. Fitzgerald M, Reynolds ML, Benowitz LI. GAP-43 expression in the developing rat lumbar spinal cord. Neuroscience 1991;41:187199.

121. Chong MS, Fitzgerald M, Winter J, et al. GAP-43 mRNA in rat spinal cord and dorsal root ganglia neurons: developmental changes and re-expression following peripheral nerve injury. Eur J Neurosci 1992;4:883-895.

122. Schreyer DJ, Skene JH. Injury-associated induction of GAP-43 expression displays axon branch specificity in rat dorsal root ganglion neurons. J Neurobiol 1993;24:959-970.

123. Brushart TM, Hoffman PN, Royall RM, Murinson BB, Witzel C, Gordon T. Electrical stimulation promotes motoneuron regeneration without increasing its speed or conditioning the neuron. J Neurosci 2002;22:6631-6638.

124. Al-Majed AA, Neumann CM, Brushart TM, Gordon T. Brief electrical stimulation promotes the speed and accuracy of motor axonal regeneration. J Neurosci 2000;20:2602-2608.
125. Udina E, Furey M, Busch S, Silver J, Gordon T, Fouad K. Electrical stimulation of intact peripheral sensory axons in rats promotes outgrowth of their central projections. Exp Neurol 2008;210:238-247.

126. Hollis II ER, Lu P, Blesch A, Tuszynski MH. IGF-I gene delivery promotes corticospinal neuronal survival but not regeneration after adult CNS injury. Exp Neurol 2009;215:53-59.

127. Ozdinler PH, Macklis JD. IGF-I specifically enhances axon outgrowth of corticospinal motor neurons. Nat Neurosci 2006;9:1371-1381.

128. Blits B, Dijkhuizen PA, Boer GJ, Verhaagen J. Intercostal nerve implants transduced with an adenoviral vector encoding neurotrophin-3 promote regrowth of injured rat corticospinal tract fibers and improve hindlimb function. Exp Neurol 2000;164:25-37.

129. Schnell L, Schneider R, Kolbeck R, Barde YA, Schwab ME. Neurotrophin-3 enhances sprouting of corticospinal tract during development and after adult spinal-cord lesion. Nature 1994;367:170-173.

130. Condic ML. Adult neuronal regeneration induced by transgenic integrin expression. J Neurosci 2001;21:4782-4788.

131. Wong LF, Yip PK, Battaglia A, et al. Retinoic acid receptor beta2 promotes functional regeneration of sensory axons in the spinal cord. Nat Neurosci 2006;9:243-250.

132. Hollis II ER, Jamshidi P, Löw K, Blesch A, Tuszynski MH. Induction of corticospinal regeneration by lentiviral trkB-induced Erk activation. Proc Natl Acad Sci U S A 2009;106:7215-7220.

133. Maehama T, Dixon JE. The tumor suppressor, PTEN/MMAC1, dephosphorylates the lipid second messenger, phosphatidylinositol 3,4,5-trisphosphate. J Biol Chem 1998;273:13375-13378.

134. Stambolic V, Suzuki A, de la Pompa JL, et al. Negative regulation of $\mathrm{PKB} / \mathrm{Akt}$-dependent cell survival by the tumor suppressor PTEN. Cell 1998;95:29-39.

135. Sun H, Lesche R, Li DM, et al. PTEN modulates cell cycle progression and cell survival by regulating phosphatidylinositol 3,4,5,-trisphosphate and Akt/protein kinase B signaling pathway. Proc Natl Acad Sci U S A 1999;96:6199-6204.

136. Liu K, Lu Y, Lee JK, et al. PTEN deletion enhances the regenerative ability of adult corticospinal neurons. Nat Neurosci 2010;13:1075-1081.

137. Park KK, Liu K, Hu Y, et al. Promoting axon regeneration in the adult CNS by modulation of the PTEN/mTOR pathway. Science 2008;322:963-966.

138. Lemon RN, Griffiths J. Comparing the function of the corticospinal system in different species: Organizational differences for motor specialization? Muscle Nerve 2005;32:261-279.

139. Eriksdotter Jonhagen M, Nordberg A, Amberla K, et al. Intracerebroventricular infusion of nerve growth factor in three patients with Alzheimer's disease. Dement Geriatr Cogn Disord 1998;9: 246-257.

140. Tuszynski MH. Growth-factor gene therapy for neurodegenerative disorders. Lancet Neurol 2002;1:51-57. 